\begin{tabular}{r} 
Państwo i Społeczeństwo \\
\hline 2018 (XVIII) nr 3 \\
e-ISSN 2451-0858 \\
ISSN 1643-8299
\end{tabular}

doi.org/10.31749/pismzp2018/20847

Magdalena Słapińska ${ }^{1}$, Tomasz Senderek ${ }^{2}$, Filip Gołkowski ${ }^{1}$

1. Krakowska Akademia im. Andrzeja Frycza Modrzewskiego, Wydział Lekarski i Nauk o Zdrowiu, Katedra Endokrynologii i Chorób Wewnętrznych

2. Krakowska Akademia im. Andrzeja Frycza Modrzewskiego, Wydział Lekarski i Nauk o Zdrowiu, Katedra Fizjologii i Patofizjologii

\title{
ZMIENNOŚĆ WYNIKU POMIARU CIŚNIENIA TĘTNICZEGO KRWI W ZALEŻNOŚCI OD PROCEDURY JEGO WYKONANIA U PACJENTA Z KONTROLOWANYM IDIOPATYCZNYM NADCIŚNIENIEM TĘTNICZYM
}

\author{
Autor do korespondencyjny: \\ Tomasz Senderek, Krakowska Akademia im. Andrzeja Frycza Modrzewskiego, Wydział Lekarski \\ i Nauk o Zdrowiu, ul. G. Herlinga Grudzińskiego 1, 30-705 Kraków \\ e-mail: tsenderek@afm.edu.pl
}

\section{Streszczenie}

Wprowadzenie: Nadciśnienie tętnicze (NT) - powszechna choroba populacji wymagająca stałego, skutecznego leczenia, aby zapobiegać powikłaniom, wśród nich zawałowi serca, udarowi mózgu i niewydolności serca. Dobór leku i jego dawki zależy od wyników pomiaru ciśnienia tętniczego krwi (CTK), wykonywanego przez samych chorych, ale także przez lekarza (pomiar gabinetowy) $\mathrm{i}$ innych pracowników służby zdrowia (pomiary ambulatoryjne). Szczególne znaczenie, ze względu na istotność podejmowania prawidłowych decyzji terapeutycznych, ma standaryzacja pomiaru gabinetowego.

Celem pracy było określenie zmienności trzech kolejno wykonanych u chorego wyników pomiaru CTK w zależności od płci, wieku, indeksu masy ciała (body mass index, BMI), palenia tytoniu, współobecności wybranych chorób przewlekłych (cukrzycy, DM), przewlekłej obturacyjnej choroby płuc (POChP) i astmy oskrzelowej oraz stosowanego leczenia hipotensyjnego.

Materiał i metody: U 130 chorych z pierwotnym NT wykonano w gabinecie kardiologicznym trzykrotny pomiar CTK: 1 . w pozycji siedzącej natychmiast po wejściu do gabinetu; 
2. po 10 minutach w pozycji siedzącej; 3 . po 15 minutach w pozycji leżącej. W oparciu o wywiad lekarski i dokumentację chorych zebrano dane dotyczące: BMI, chorób współistniejących, aktualnie przyjmowanych leków i palenia tytoniu.

Wyniki: Wykazano istotną statystycznie zmienność wyniku pomiaru CTK w zależności od pozycji i czasu wykonania pomiaru, niezależnie od płci, wieku, BMI i stosowanego leczenia hipotensyjnego. Nie stwierdzono zmienności wyników pomiaru ze współistniejąca cukrzycą, astmą oskrzelową ani POChP. Najwyższe wartości CTK stwierdzono w czasie pierwszego pomiaru, niższe w dwóch kolejnych.

Wnioski: Pozycja ciała i czas, jaki upłynął od początku wizyty, wpływają na wynik pomiaru CTK, poza grupami chorych, w których powikłania choroby lub stosowane leczenie mogą niwelować różnicę (cukrzyca, astma oskrzelowa, POChP). Uzyskane wyniki potwierdzają konieczność ostrożnej oceny wyniku pomiaru gabinetowego CTK.

Słowa kluczowe: leczenie przeciwnadciśnieniowe, nadciśnienie pierwotne, pomiar ciśnienia tętnicznego

\section{Wprowadzenie}

Nadciśnienie tętnicze (NT) jest jednym z głównych czynników ryzyka chorób układu krążenia i ośrodkowego układu nerwowego (OUN), jak zawał serca, udar mózgu oraz niewydolność serca. Wśród krajów europejskich Polska odznacza się wysoką umieralnością z powodu chorób układu sercowo-naczyniowego mimo nowoczesnego podejścia terapeutycznego $\mathrm{w}$ ich leczeniu. W badaniu NATPOL z r. 2011 rozpoznano NT u 32\% Polaków; jest jednak możliwe, że chorych jest nawet o ok. trzy miliony więcej $[1,2,3]$.

NT przez długi czas rozwija się bezobjawowo, lecz z upływem lat doprowadza do poważnych powikłań. Chorobę nadciśnieniową wykrywa się najczęściej podczas kontrolnego pomiaru ciśnienia tętniczego krwi (CTK). Ze względy na dużą zmienność wartości CTK, zależną od takich czynników jak stan emocjonalny, wysiłek fizyczny czy spożycie posiłku, istotne jest ścisłe przestrzeganie standardów pomiaru zgodnie z wytycznymi Europejskiego Towarzystwa Nadciśnienia Tętniczego / Europejskiego Towarzystwa Kardiologiczne ESH/ESC (European Society of Hypertension / European Society of Cardiology), opublikowanymi w 2013 r. [4]. W leczeniu NT kwestią kluczową dla wybrania właściwego leczenia są wyniki samokontrolnych pomiarów CTK w warunkach domowych $\mathrm{w}$ zestawieniu $\mathrm{z}$ badaniem CTK $\mathrm{w}$ gabinecie [3].

Wartość CTK zależy od rzutu serca (cardiac output, CO) oraz oporu przepływu krwi w układzie naczyniowym. Ciśnienie tętnicze podlega złożonej regulacji ze strony układu hormonalnego, układu nerwowego i czynności nerek. W aktywnej regulacji ciśnienia tętniczego krwi wyróżniamy zwłaszcza układ renina-angiotensyna-aldosteron (działający długoterminowo) i układ współczulno-nadnerczowy (o działaniu natychmiastowym); ponadto modyfikujące działanie odgrywają: neuropeptyd $\mathrm{Y}$, peptydy natriuretyczne oraz substancje presyjne 
i hipotensyjne wytwarzane w komórkach śródbłonka naczyń. Najszybciej działającym mechanizmem monitorowania i regulacji CTK są receptory zlokalizowane w mięśniu sercowym i w płucach (mechanoreceptory sercowo-płucne), w tętnicach (mechanoreceptory i ich odmiana znana - baroreceptory) oraz mięśniach szkieletowych (ergoreceptory). Ponadto znaczenie mają chemoreceptory kłębków aortalnych i szyjnych, zlokalizowane wzdłuż łuku aorty i w rozgałęzieniu tętnic szyjnych wspólnych $[4,5,6,7]$.

Wartość ciśnienia tętniczego krwi określa się przy pomocy ciśnieniomierza, stosując metody pomiaru: manualną, osłuchową lub oscylometryczną. Metoda osłuchowa polega na detekcji tonów Korotkowa za pomocą stetoskopu [8].

Zaleca się, aby rozmiar mankietu był indywidualnie dobrany do grubości ramienia chorego. Należy poinformować chorego o przebiegu badania. Konieczny jest kilkuminutowy odpoczynek bezpośrednio przed wykonaniem pomiaru. Zaleca się wykonanie co najmniej dwóch pomiarów; w przypadku znacznej różnicy wartości CTK należy rozważyć uśrednienie uzyskanych wyników [3,4,9].

Nadciśnienie tętnicze rozpoznaje się, jeśli średnia wartość CTK, uzyskana podczas co najmniej dwóch różnych wizyt lekarskich, jest większa lub równa 140/90 mmHg. Wartości prawidłowe zmodyfikowano dla chorych w podeszłym wieku lub z chorobami współistniejącymi, jak cukrzyca, przewlekła choroba nerek, stan po zawale serca lub udarze mózgu $[4,10]$.

Dopuszczalne jest rozpoznanie choroby nadciśnieniowej, jeżeli wartość CTK pojedynczego pomiaru przekracza 180/110mm Hg i wykluczono czynniki, które mogą tę wartość podwyższyć. Wyróżnia się trzy stopnie NT (tab. 1) [11,12].

Tabela 1. Klasyfikacja nadciśnienia tętniczego w pomiarach gabinetowych

\begin{tabular}{lccc}
\hline Klasyfikacja & $\begin{array}{c}\text { Ciśnienie skurczowe } \\
{[\mathrm{mm} \mathrm{Hg}]}\end{array}$ & & $\begin{array}{c}\text { Ciśnienie rozkurczowe } \\
{[\mathrm{mm} \mathrm{Hg}]}\end{array}$ \\
\cline { 2 - 4 } Optymalne & $<120$ & $\mathrm{i}$ & $<80$ \\
Prawidłowe & $120-129$ & $\mathrm{i} / \mathrm{lub}$ & $80-84$ \\
Wysokie prawidłowe & $130-139$ & $\mathrm{i} / \mathrm{lub}$ & $85-89$ \\
Nadciśnienie tętnicze 1 stopnia & $140-159$ & $\mathrm{i} / \mathrm{lub}$ & $90-99$ \\
Nadciśnienie tętnicze 2 stopnia & $160-179$ & $\mathrm{i} / \mathrm{lub}$ & $100-109$ \\
Nadciśnienie tętnicze 3 stopnia & $\geq 180$ & $\mathrm{i} / \mathrm{lub}$ & $\geq 110$ \\
\hline
\end{tabular}

Podstawowym problemem technicznym jest błędnie dobrany mankiet lub nieprawidłowe jego założenie. Skutkuje to fałszywą oceną wartości CTK i niewłaściwą interpretacją wyniku [13].

Ważnym elementem diagnostyki NT są pomiary wykonywane samokontrolnie w warunkach domowych chorego, co po instruktażu badającego pozwala 
uzyskać relatywnie dobrze odzwierciedlające stopień kontroli choroby i w konsekwencji optymalizować leczenie [3,8].

Kolejną metodą w diagnostyce nadciśnienia tętniczego jest Holter ciśnieniowy, w którym monitorowanie CTK odbywa się co 15-30 min. w ciągu dnia i 30-60 min. w ciągu nocy $[12,13]$.

Celem terapii NT jest obniżenie CTK do wartości uznanych za docelowe lub najbardziej do nich zbliżonych i w konsekwencji maksymalne zmniejszenie ryzyka powikłań sercowo-naczyniowych. Leczenie NT polega na farmakoterapii i zmianie stylu życia $[3,15]$. Istotną rolę w terapii NT odgrywa leczenie niefarmakologiczne $[12,16]$.

Leczenie farmakologiczne opiera się na pięciu głównych grupach leków: diuretyków tiazydowych/tiazydopodobnych, beta-adrenolityków (beta-blokerów), antagonistów wapnia (blokerów kanału wapniowego), inhibitorów konwertazy angiotensyny (hamujych enzym konwertazę angiotensyny I, ACE-I) oraz sartanów (blokerów receptora angiotensyny). Leki te należą do farmakoterapii I rzutu, która wykazuje korzystny wpływ na śmiertelność sercowo-naczyniową. Najczęściej leczenie hipotensyjne rozpoczyna się od monoterapii, w razie potrzeby wprowadza się terapię skojarzoną dwulekową. Właściwy dobór leków zależy m.in. od wieku, płci, stopnia NT i chorób współistniejących.

W przypadku istnienia wskazań indywidualnych lub NT opornego na dotychczasowe leczenie, stosuje się inne leki hipotensyjne, jak diuretyki pętlowe, antagoniści aldosteronu, alfa-adrenolityki, centralne i obwodowe sympatykolityki. U części chorych przyjmuje to postać terapii skojarzonej wielolekowej [3].

\section{Cele badania}

1. Potwierdzenie, że procedura (pozycja chorego, czas wykonania) pomiaru CTK w warunkach porady gabinetowej wpływa na jego wynik.

2. Ocena zależności zmienności wyników pomiaru CTK od płci, wieku, BMI i palenia tytoniu.

3. Określenie, czy wybrane choroby przewlekłe (cukrzyca, POChP, astma oskrzelowa, przebyty zawał serca i udar mózgu ) wpływają na zmienność pomiaru CTK.

4. Ocena zależności zmienności wyniku pomiaru CTK od stosowanego leczenia hipotensyjnego.

\section{Material i metody}

Badanie wykonano w NZOZ w Wieliczce w okresie od września 2016 r. do maja 2017 r. po uzyskaniu pozytywnej opinii Komisji Bioetycznej Krakowskiej Akademii im. A. Frycza Modrzewskiego (nr zgody 19/2016). 
Do badania włączono 130 chorych, wszyscy podpisali świadomą zgodę na udział w badaniu. Kryteriami włączenia było posiadanie dzienniczka ciśnieniowego z odnotowanymi, co najmniej dwoma pomiarami CTK dziennie, prowadzonymi przez ostatnie dwa tygodnie przed wizytą. Kryteriami wyłączenia były odnotowane wartości ciśnienia tętniczego krwi przekraczające 180/100 mmHg (niedostateczna kontrola farmakologiczna wartości CTK) w ostatnich czternastu dniach w dzienniczku ciśnieniowym, obecność przewlekłych zespołów bólowych, udokumentowanych chorób psychicznych lub ciężki stan ogólny zdrowia chorego (wg subiektywnej oceny lekarza prowadzącego).

W gabinecie trzykrotnie mierzono CTK u każdej osoby na obu ramionach za pomocą ciśnieniomierza sprężynowego Viso Spencer. Pomiary dokonano w odstępach czasowych:

1. pierwszy pomiar natychmiast po wejściu do gabinetu w pozycji siedzącej,

2. drugi pomiar 10 minut później również w pozycji siedzącej,

3. trzeci w 15 minut od pierwszego pomiaru w pozycji leżącej.

Dodatkowo mierzono tętno i saturację hemoglobiny przy pomocy pulsoksymetru (Beurer PO40). Zebrano wywiad i sprawdzono w dokumentacji lekarskiej informacje dotyczące: BMI, chorób współistniejących, farmakoterapii i palenia tytoniu. Efekt „białego fartucha” oceniono, porównując wartości pomiarów CTK ,gabinetowych” ze średnimi wartościami ciśnienia pochodzącymi z dzienniczka samokontroli pacjentów.

Wszystkie zebrane informacje gromadzono w sposób uniemożliwiający identyfikację chorych. Uzyskane wyniki poddano analizie statystycznej w programie IBM SPSS Statistics 23.0. Rozkład wyników oszacowano na podstawie wartości skośności i kurtozy, które dla uzyskanych parametrów nie przekroczyły przedziału $<-1,1>$. Potwierdza to zgodność rozkładu wyników badanych parametrów z rozkładem normalnym oraz pozwoliło na zastosowanie w dalszych obliczeniach testu $t$ dla prób zależnych w celu porównania różnicy CTK na prawym i lewym ramieniu oraz procedury parametrycznej, tzn. analizy wariancji $A N O V A$ z powtarzanym pomiarem, gdzie czynnikiem był czas pomiaru (pomiar 1 vs pomiar 2 vs pomiar 3). Analizę wykonano dla grupy badanej ogółem, a następnie z podziałem kolejno na płeć (kobieta vs mężczyzna), wiek ( $<50$ lat vs $50-65$ lat vs $>65$ lat), obecność chorób współistniejących tj. cukrzycy, astmy, POCHP, przebytego zawału serca, przebytego udaru mózgu (tak vs nie), BMI (niedowaga vs waga prawidłowa vs nadwaga vs otyłość), insulinoterapię (tak vs nie), farmakoterapię (monoterapia vs terapia dwulekowa vs terapia wielolekowa), palenie tytoniu (tak vs nie). Zmienną zależną była wartość CTK skurczowego i rozkurczowego, uśredniona z prawego i lewego ramienia. Porównania parami post hoc wykonano z zastosowaniem poprawki dla porównań wielokrotnych Bonferroniego. Istotność statystyczną wyników przyjęto na poziomie $p<0,05$. 


\section{Wyniki}

Badana grupa składała się z 130 osób: 60,8\% kobiet i 39,2\% mężczyzn, w wieku $25-87$ lat $(M=58,88 ; S D=13,86)$. Charakterystykę grupy przedstawiono w tabelach 2 i 3 . Wszyscy chorzy stosowali leczenie farmakologiczne NT (tab. 4).

Tabela 2. Dane demograficzne grupy badanej

\begin{tabular}{|c|c|c|c|}
\hline & & $\mathrm{N}$ & $\%$ \\
\hline \multirow{3}{*}{ Płeć } & Kobiety & 79 & $60,8 \%$ \\
\hline & Mężczyźni & 51 & $39,2 \%$ \\
\hline & Poniżej 50 lat & 35 & $26,9 \%$ \\
\hline \multirow[t]{2}{*}{ Wiek } & 50-65 lat & 49 & $37,7 \%$ \\
\hline & Powyżej 65 lat & 46 & $35,4 \%$ \\
\hline \multirow{2}{*}{ Palenie } & Tak & 46 & $35,4 \%$ \\
\hline & Nie & 84 & $64,6 \%$ \\
\hline \multirow{6}{*}{ BMI } & $<18,5$ (niedowaga) & 0 & $0,0 \%$ \\
\hline & $18,5-24,9$ (waga prawidłowa) & 22 & $16,9 \%$ \\
\hline & 25-29,9 (nadwaga) & 63 & $48,5 \%$ \\
\hline & 30-34,9 (otyłość I stopnia) & 35 & $26,9 \%$ \\
\hline & 35-39,9 (otyłość II stopnia) & 7 & $5,4 \%$ \\
\hline & > 40 (otyłość III stopnia) & 3 & $2,3 \%$ \\
\hline
\end{tabular}

Tabela 3. Częstość występowania wybranych chorób przewlekłych w badanej grupie

\begin{tabular}{cccc}
\hline Choroby współistniejące & & $\mathrm{N}$ & $\%$ \\
\cline { 3 - 4 } Cukrzyca typu I & Tak & 7 & $5,4 \%$ \\
& Nie & 123 & $94,6 \%$ \\
\cline { 2 - 4 } Cukrzyca typu II & Tak & 13 & $10,0 \%$ \\
& Nie & 117 & $90,0 \%$ \\
\cline { 2 - 4 } Astma oskrzelowa & Tak & 6 & $4,6 \%$ \\
POChP & Nie & 124 & $95,4 \%$ \\
\cline { 2 - 4 } Inne choroby współistniejące & Tak & 12 & $9,2 \%$ \\
& Nie & 118 & $90,8 \%$ \\
\cline { 2 - 4 } & Tak & 43 & $33,1 \%$ \\
Udar mózgu & Nie & 87 & $66,9 \%$ \\
\cline { 2 - 4 } & Tak & 8 & $6,2 \%$ \\
Zawał serca & Nie & 122 & $93,8 \%$ \\
\hline & Tak & 7 & $5,4 \%$ \\
\cline { 2 - 4 } & Nie & 123 & $94,6 \%$ \\
\hline
\end{tabular}


Tabela 4. Leki stosowane w terapii badanych osób

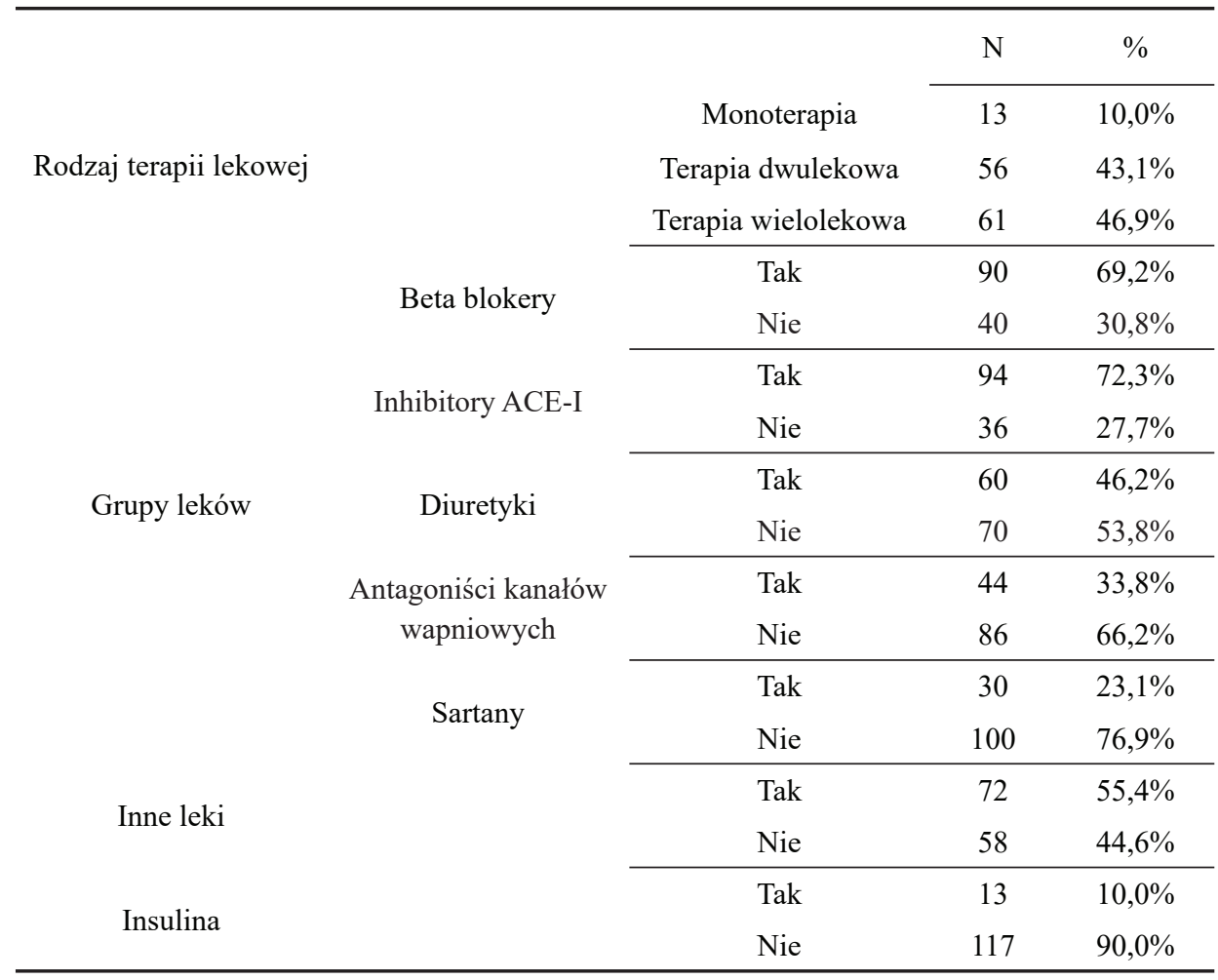

Wszystkie poniższe wyniki przedstawiono w milimetrach słupa rtęci.

W analizie pomiarów CTK, uzyskanych wg danych dzienniczków ciśnieniowych, badane osoby uzyskały wynik wysoki prawidłowy w przypadku ciśnienia tętniczego skurczowego $(M=130,31)$ i wynik optymalny w przypadku ciśnienia tętniczego rozkurczowego $(M=76,81)$.

W trzykrotnym pomiarze gabinetowym CTK w opisanych wyżej odstępach czasowych w przypadku ciśnienia tętniczego skurczowego prawego ramienia uzyskano w pomiarze pierwszym wynik klasyfikujący nadciśnienie tętnicze do II stopnia $(M=161,35)$, w pomiarze drugim i trzecim - do I stopnia (pomiar drugi: $M=150,08$; pomiar trzeci: $M=147,31$ ). W przypadku ciśnienia tętniczego skurczowego lewego ramienia w każdym z trzech pomiarów uzyskano wynik klasyfikujący NT do stopnia I (pomiar oierwszy: $M=158,92$; pomiar drugi: $M=146,42$; pomiar trzeci: $M=146,42$ ) (ryc. 1). W przypadku średniego ciśnienia tętniczego skurczowego prawego i lewego ramienia w pomiarze pierwszym uzyskano wynik klasyfikujący NT do II stopnia $(M=160,40)$, w pomiarze drugim i trzecim - do I stopnia (pomiar drugi: $M=149,33$; pomiar trzeci: $M=146,94$ ) (tab. 5). 
Tabela 5. Porównanie ciśnienia tętniczego skurczowego i rozkurczowego prawego i lewego przedramienia

\begin{tabular}{|c|c|c|c|c|c|c|c|c|c|}
\hline & \multirow[b]{2}{*}{ Pomiar } & \multicolumn{2}{|c|}{$\begin{array}{c}\text { Prawa kończyna } \\
\text { górna }\end{array}$} & \multicolumn{2}{|c|}{$\begin{array}{l}\text { Lewa kończyna } \\
\text { górna }\end{array}$} & \multirow{2}{*}{$\begin{array}{c}\text { Porównanie } \\
\text { średnich }\end{array}$} & \multicolumn{3}{|c|}{ Statystyki testu $t$} \\
\hline & & $M$ & $S D$ & $M$ & $S D$ & & $t$ & $D f$ & $p$ \\
\hline & 1 & 161,35 & 12,57 & 158,92 & 12,62 & $\mathrm{P}>\mathrm{L}$ & 4,27 & 129 & $<0,001$ \\
\hline \multirow{3}{*}{$\begin{array}{c}\text { CTK } \\
\text { skurczowe } \\
{[\mathrm{mm} \mathrm{Hg}]}\end{array}$} & 2 & 150,08 & 13,06 & 146,42 & 21,17 & $\mathrm{P}>\mathrm{L}$ & 2,37 & 129 & $<0,02$ \\
\hline & 3 & 147,31 & 12,25 & 146,42 & 12,03 & $\mathrm{P}>\mathrm{L}$ & 3,21 & 129 & $<0,001$ \\
\hline & 1 & 88,73 & 7,63 & 87,31 & 7,90 & $\mathrm{P}>\mathrm{L}$ & 3,68 & 129 & $<0,001$ \\
\hline \multirow{2}{*}{$\begin{array}{c}\text { CTK } \\
\text { rozkurczowe } \\
{[\mathrm{mm} \mathrm{Hg}]}\end{array}$} & 2 & 85,62 & 7,29 & 84,27 & 7,26 & $\mathrm{P}>\mathrm{L}$ & 4,68 & 129 & $<0,001$ \\
\hline & 3 & 83,85 & 6,63 & 83,23 & 6,61 & $\mathrm{P}>\mathrm{L}$ & 3,01 & 129 & $<0,001$ \\
\hline
\end{tabular}

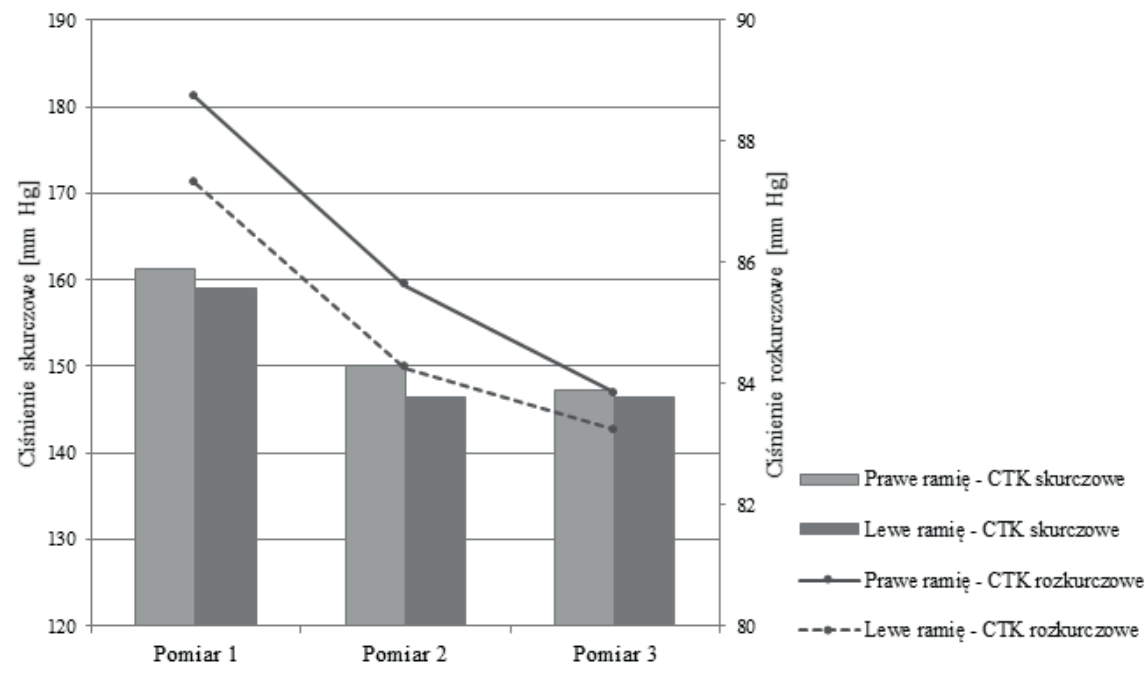

Rycina 1. Porównanie skurczowego i rozkurczowego CTK prawego i lewego ramienia

Wyniki tętna i saturacji $\mathrm{Hb}$ były prawidłowe we wszystkich trzech punktach czasowych. 
Podsumowując, zaobserwowano istotny statystycznie wpływ czasu pomiaru i pozycji ciała na wartość CTK. Porównania post hoc wykazały różnice między pomiarem pierwszym a drugim, pomiarem drugim a trzecim oraz pomiarem pierwszym a trzecim (wszystkie znamienne statystycznie). W sumie, im później wykonano pomiar, tym wartość ciśnienia tętniczego skurczowego i rozkurczowego była niższa (ryc. 2).

Analogiczne zależności obserwowano, gdy osobno analizowano kobiety i mężczyzn. W obu tych grupach, porównania post hoc wykazały istotne różnice pomiędzy pomiarem CTK pierwszym a drugim, pomiarem drugim a trzecim oraz pomiarem pierwszym a trzecim (później wykonany pomiar przekładał się na znamiennie niższą wartość ciśnienia tętniczego skurczowego i rozkurczowego (ryc. 3).

Stwierdzono istotny statystycznie efekt czasu pomiaru i pozycji ciała na wartość CTK skurczowego i rozkurczowego we wszystkich trzech grupach wiekowych (ryc. 4).

Wykazano istotny statystycznie efekt czasu pomiaru i pozycji ciała na wartość CTK wyłącznie u chorych bez cukrzycy, astmy ani POChP. W podgrupie osób bez tych chorób towarzyszących porównania post hoc wykazały istotne statystycznie różnice między pomiarami. Natomiast $\mathrm{w}$ grupie osób, która dodatkowo chorowała na cukrzycę, astmę lub POChP, nie wykazano istotnego statystycznie wpływu czasu pomiaru i pozycji ciała na wartości CTK skurczowego i rozkurczowego (ryc. 5-8).

Zaobserwowano istotny statystycznie wpływ czasu pomiaru i pozycji ciała na wartość CTK, niezależnie od wartości BMI (ryc. 9).

Zaobserwowano istotny statystycznie efekt wpływ czasu pomiaru i pozycji ciała na wartość CTK, niezależnie od liczby przyjmowanych leków hipotensyjnych (ryc. 10).

Zaobserwowano istotny statystycznie wpływ czasu pomiaru i pozycji ciała na wartość CTK, zarówno u chorych palących papierosy, jak i niepalących. Osoby niepalące $\mathrm{w}$ pierwszym pomiarze miały nieznacznie wyższe wartości skurczowego CTK od osób palących (ryc. 11).

U chorych z przebytym zawałem serca lub udarem mózgu nie stwierdzono istotnego statystycznie wpływu czasu pomiaru na wartość ciśnienia tętniczego skurczowego i rozkurczowego. Bez względu na sposób pomiaru chorzy po przebytym zawale lub udarze uzyskały podobne wartości CTK skurczowego i rozkurczowego (ryc. 12-13). Te dwie grupy chorych nie były liczne; uzyskane tu wyniki wymagają potwierdzenia w większej liczbie pacjentów.

U 78,4\% chorych (102 osoby, w tym 64 kobiety i 38 mężczyzn) średnia wartość pomiarów CTK nr 2 i 3 w gabinecie „gabinetowych” była wyższa od średnich wartości ciśnienia tętniczego pochodzących z dzienniczka samokontroli pacjentów (w obserwacji dwutygodniowej). Dla całej grupy uczestniczących w badaniu chorych zależność ta była znamienna statystycznie $(\mathrm{p}<0,05)$; ze względu na rozmiary niniejszej pracy nie prezentowano szczegółowych danych. 


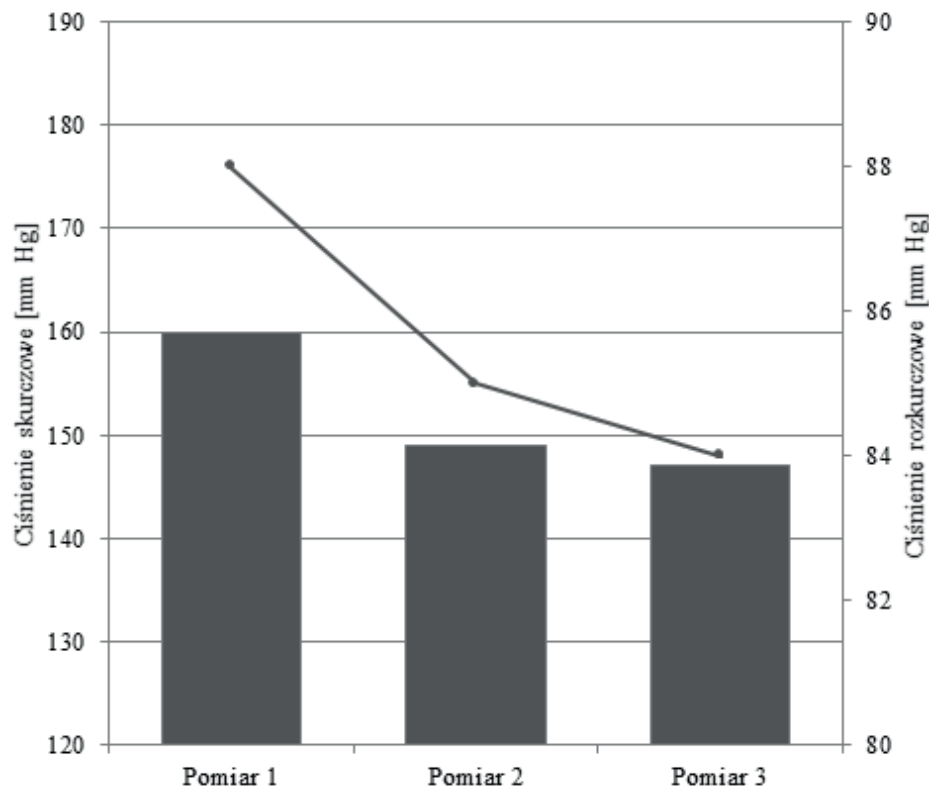

CTK skurczowe

$\rightarrow$ CTK rozkurczowe

Rycina 2. Wpływ czasu pomiaru i pozycji ciała na ciśnienie tętnicze skurczowe i rozkurczowe

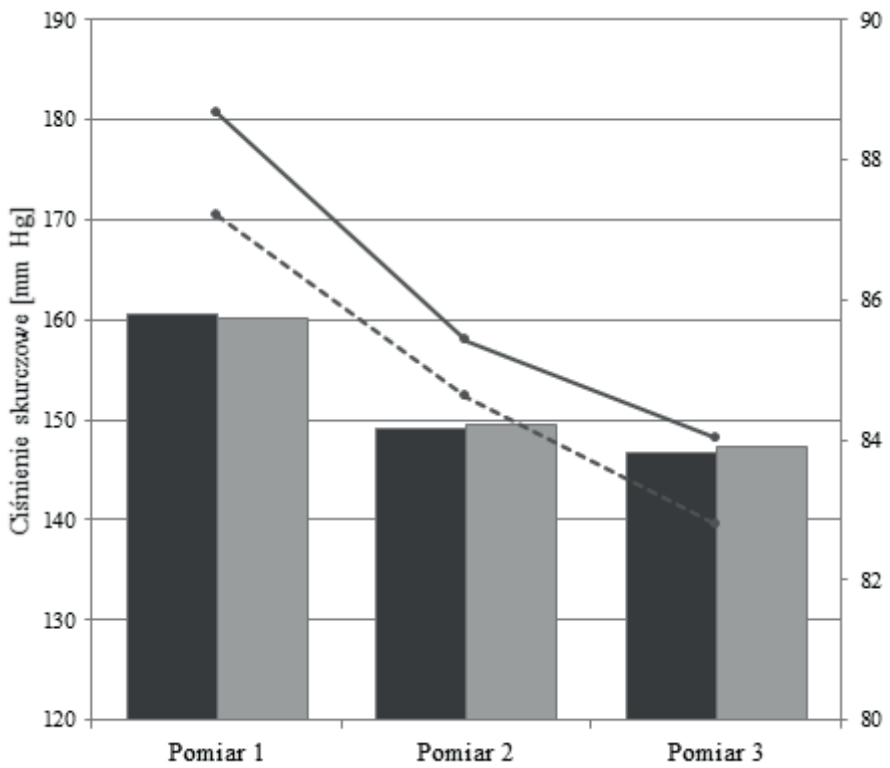

90

88

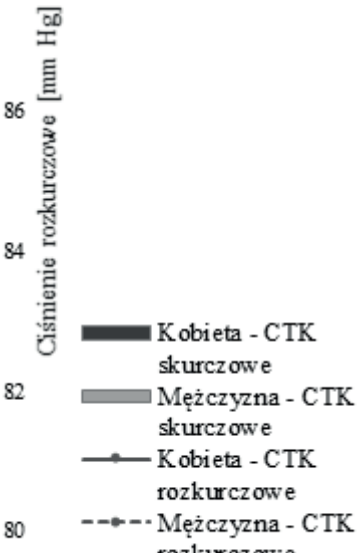
rozkurczowe

Rycina 3. Wpływ czasu pomiaru i pozycji ciała na ciśnienie tętnicze skurczowe i rozkurczowe w zależności od płci 


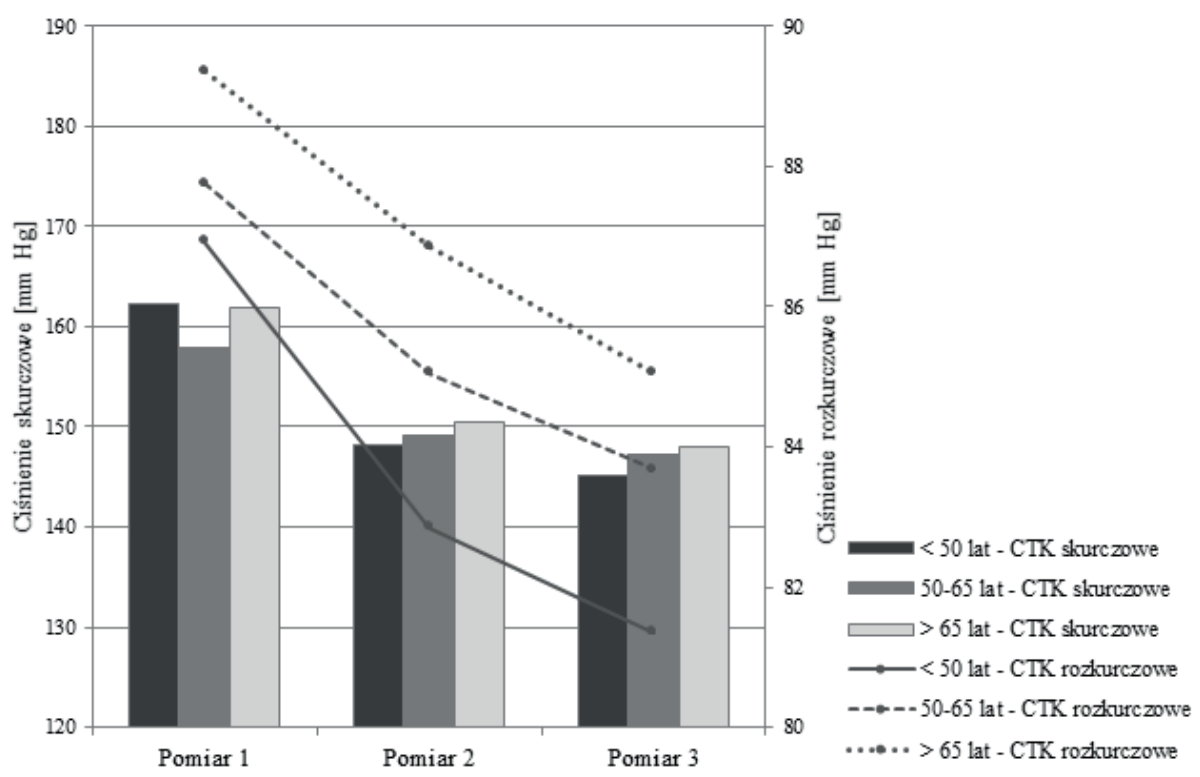

Rycina 4. Wpływ czasu pomiaru i pozycji ciała na ciśnienie tętnicze skurczowe i rozkurczowe w zależności od wieku

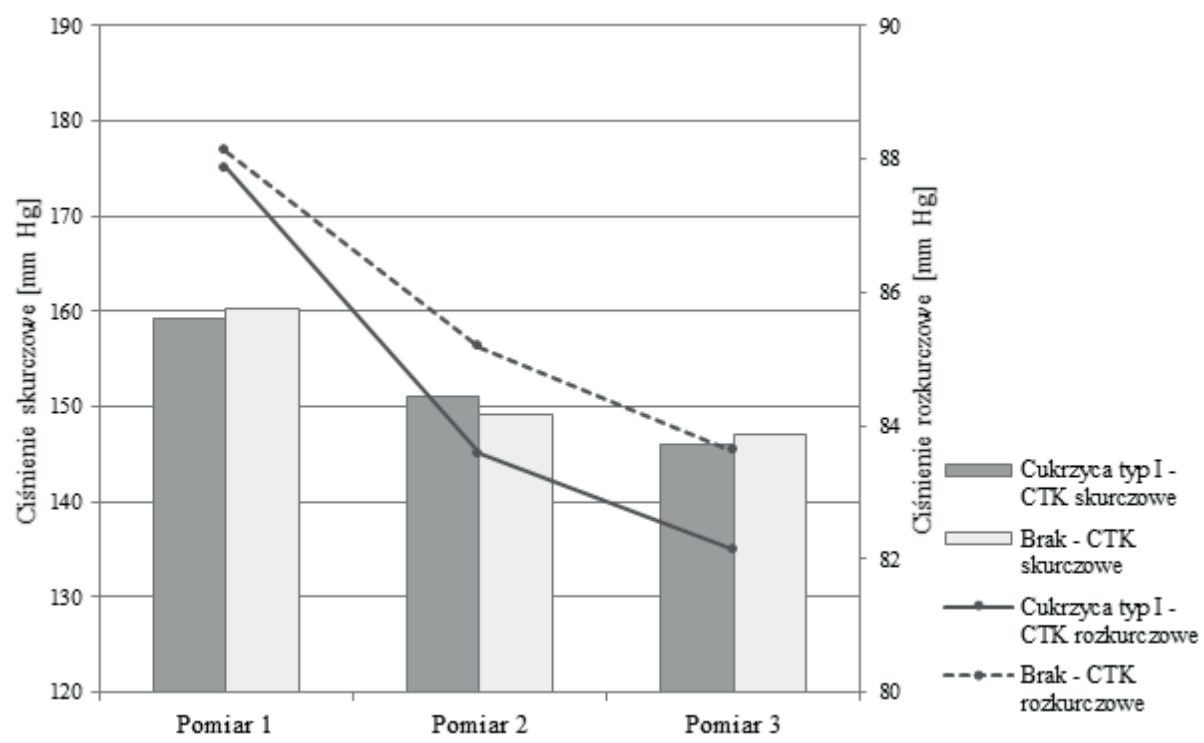

Rycina 5. Wpływ czasu pomiaru i pozycji ciała na ciśnienie tętnicze skurczowe i rozkurczowe w zależności od współwystępowania cukrzycy typu I 


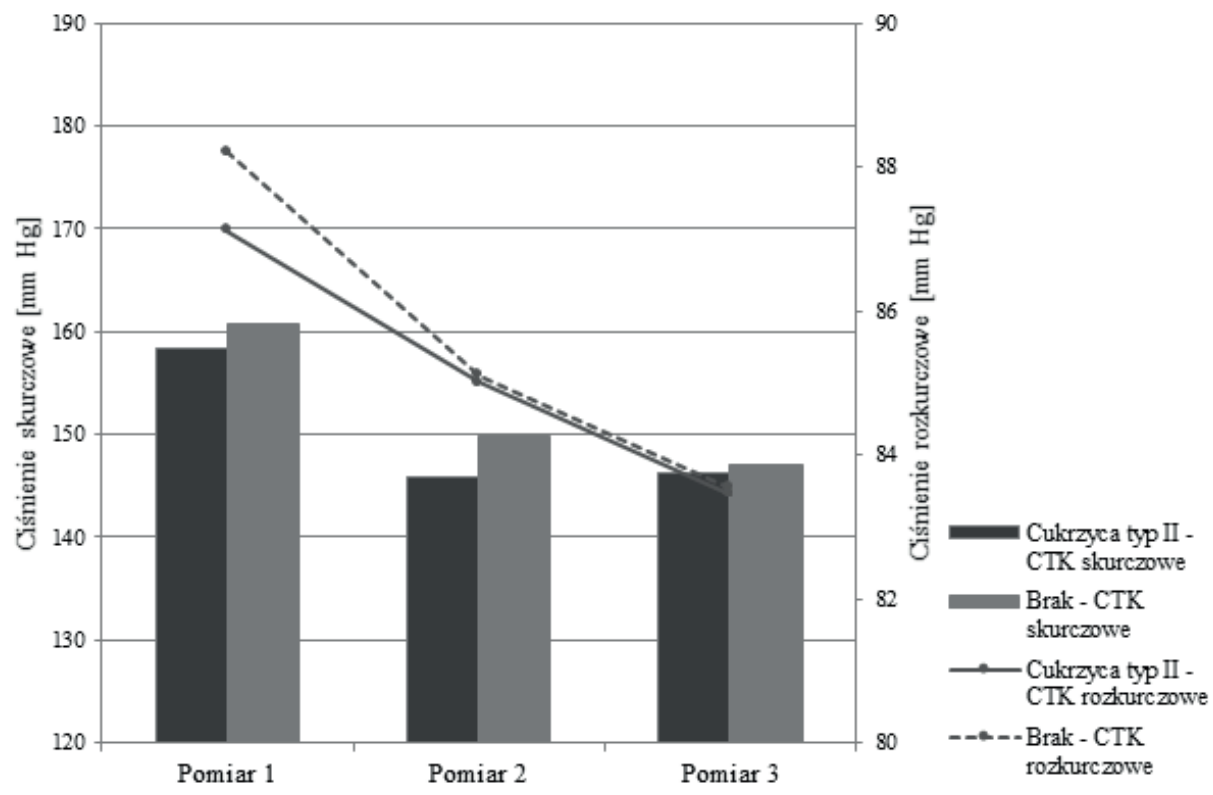

Rycina 6. Wpływ czasu pomiaru i pozycji ciała na ciśnienie tętnicze skurczowe i rozkurczowe w zależności od współwystępowania cukrzycy typy II

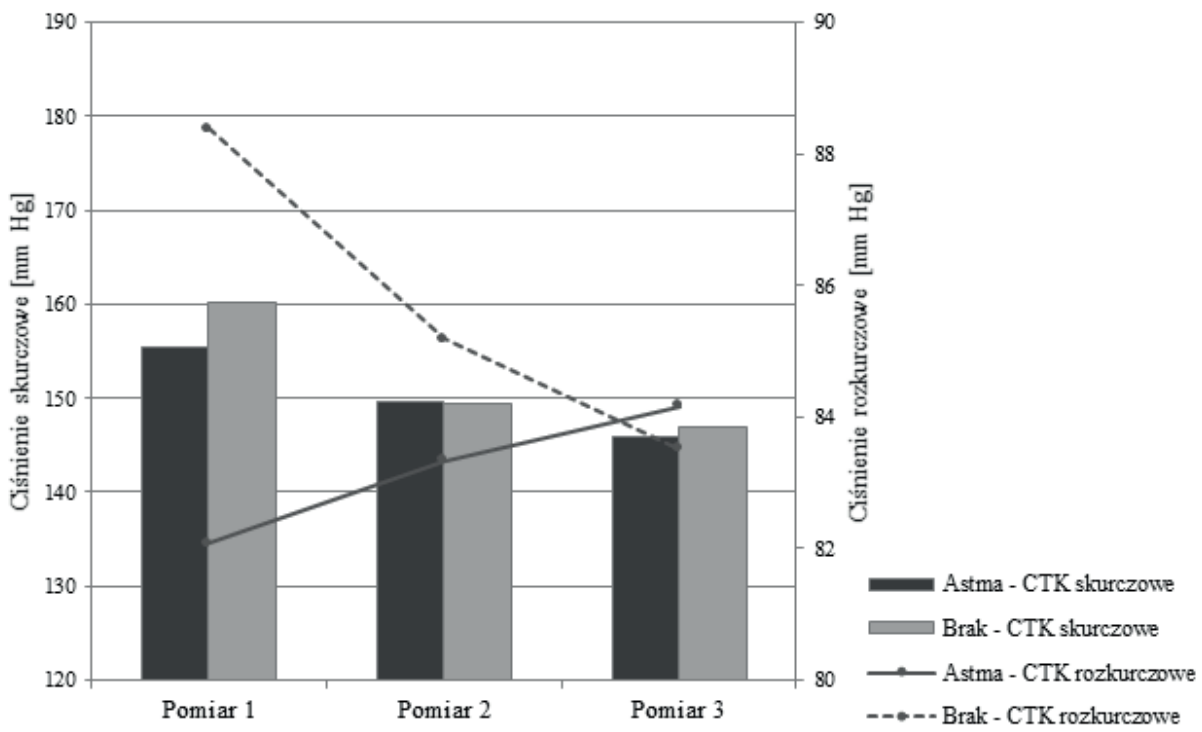

Rycina 7. Wpływ czasu pomiaru i pozycji ciała na ciśnienie tętnicze skurczowe i rozkurczowe w zależności od współwystępowania astmy oskrzelowej 


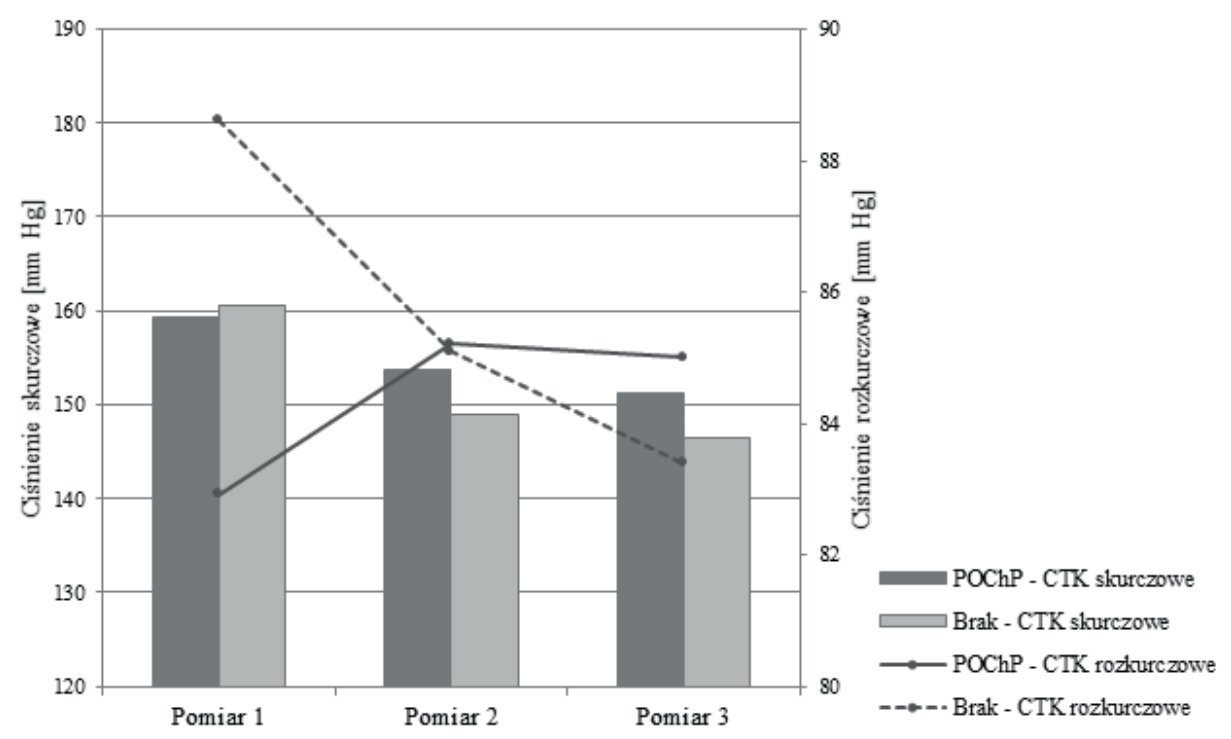

Rycina 8. Wpływ czasu pomiaru i pozycji ciała na ciśnienie tętnicze skurczowe i rozkurczowe w zależności od współwystępowania POChP
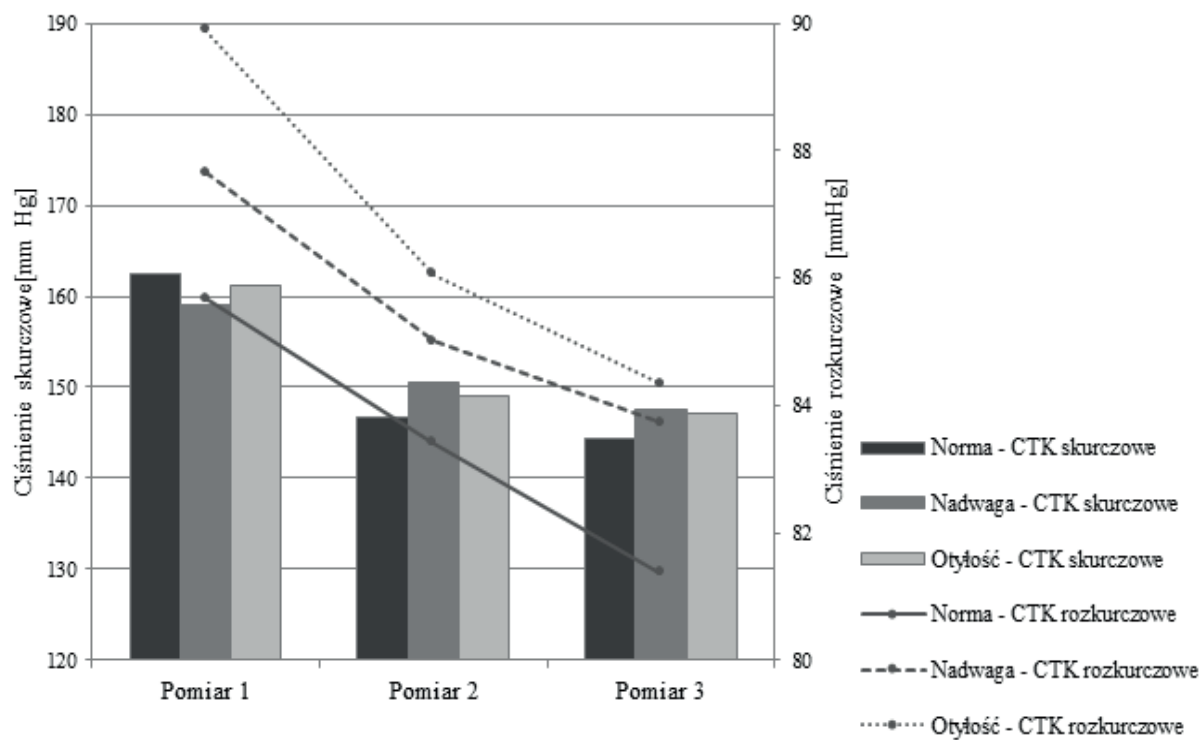

Rycina 9. Wpływ czasu pomiaru na ciśnienie tętnicze skurczowe i rozkurczowe w zależności od wartości BMI 


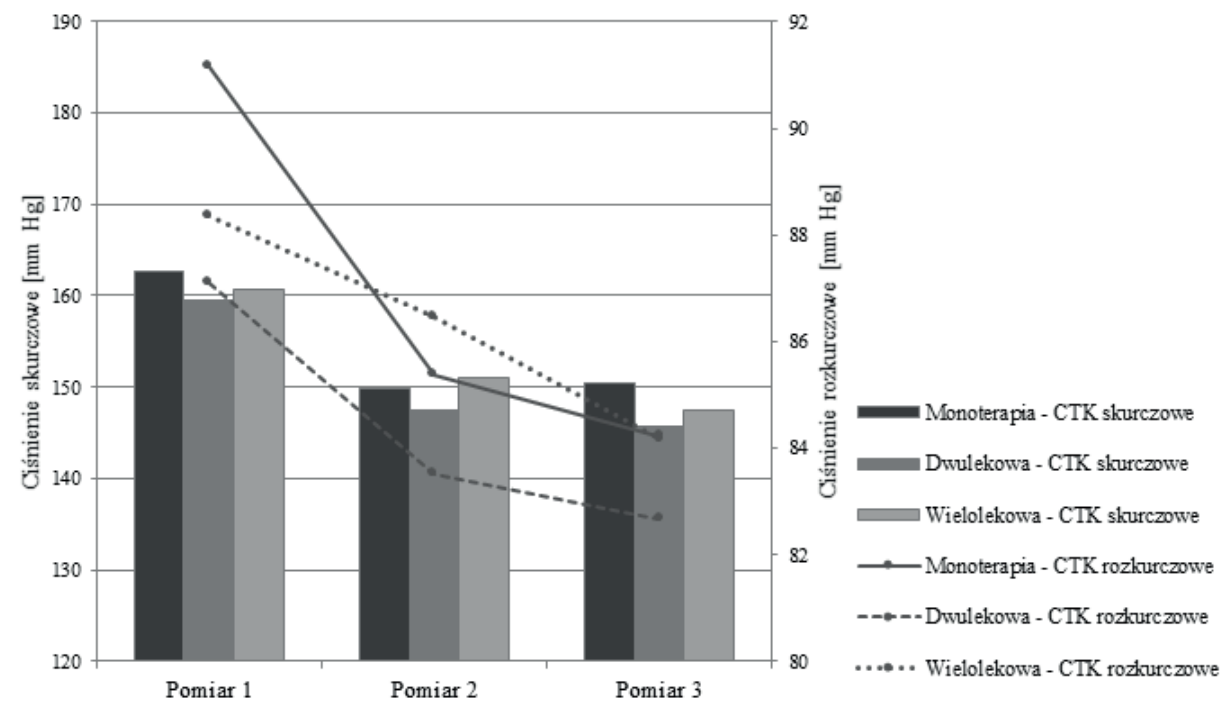

Rycina 10. Wpływ czasu pomiaru i pozycji ciała na ciśnienie tętnicze skurczowe i rozkurczowe w zależności od stosowanej terapii farmakologicznej

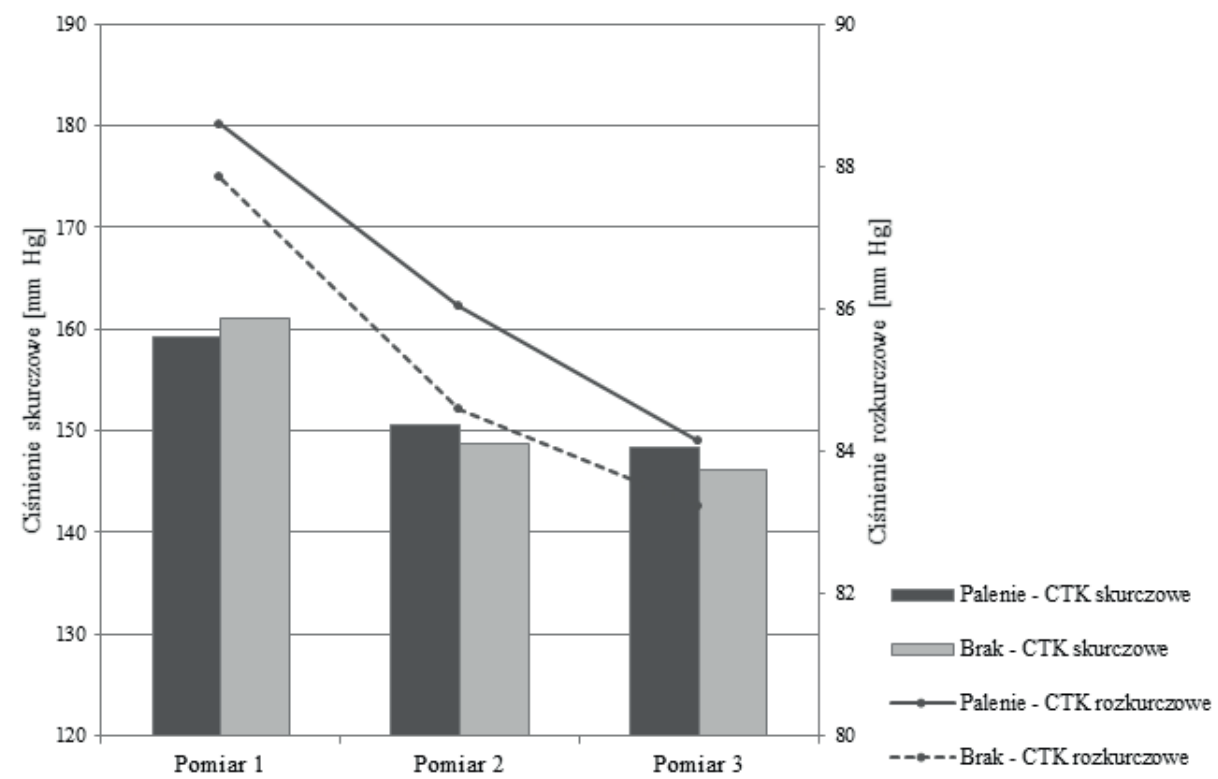

Rycina 11. Wpływ czasu pomiaru i pozycji ciała na ciśnienie tętnicze skurczowe i rozkurczowe w zależności od palenia tytoniu 

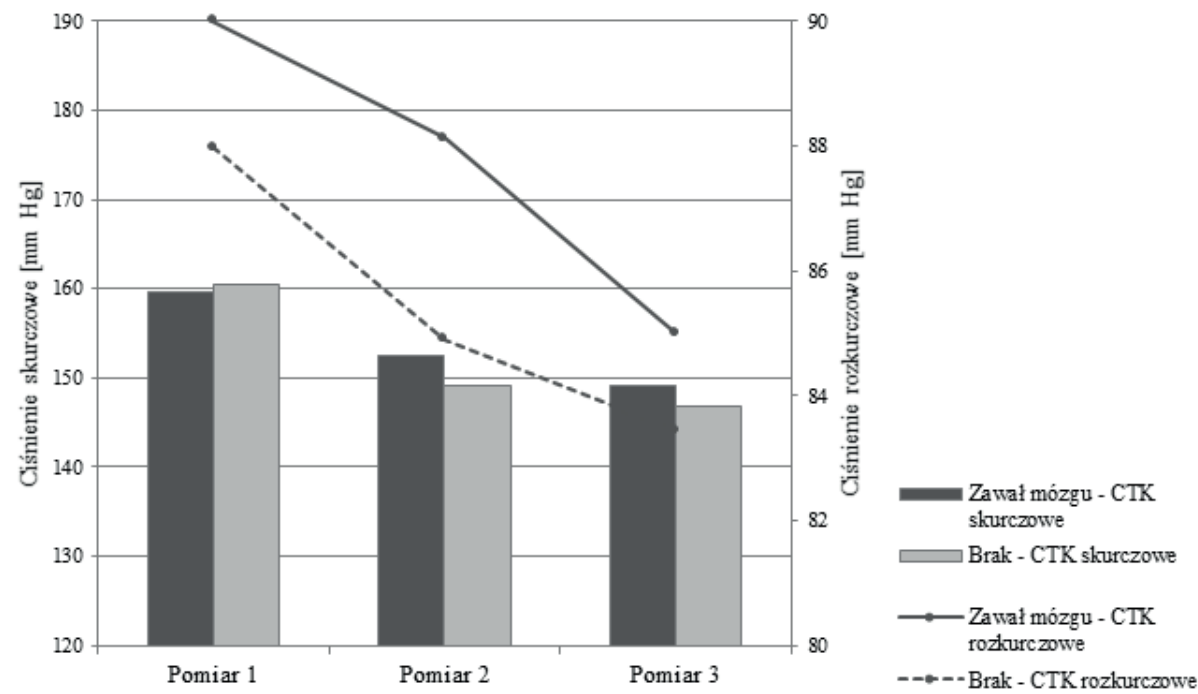

Rycina 12. Wpływ czasu pomiaru i pozycji ciała na ciśnienie tętnicze skurczowe i rozkurczowe w zależności od przebytego udaru mózgu
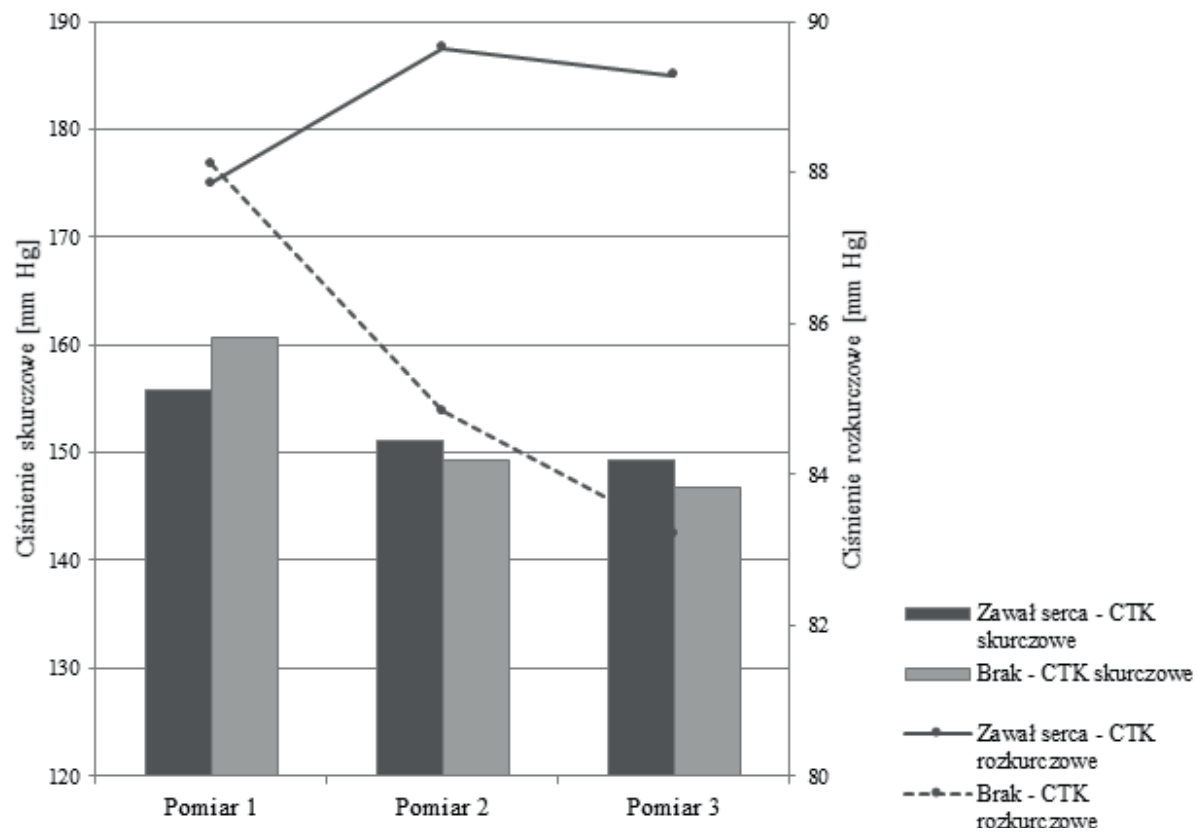

Rycina13. Wpływ czasu pomiaru i pozycji ciała na ciśnienie tętnicze skurczowe i rozkurczowe w zależności od przebytego zawału serca 


\section{Dyskusja}

Choroba nadciśnieniowa jest rozpowszechnionym czynnikiem ryzyka innych chorób, w tym powikłań sercowo-naczyniowych. NT przez długi czas może rozwijać się bezobjawowo, dlatego też często bywa rozpoznawana przypadkowo, podczas kontrolnego pomiaru CTK. Ze względy na fakt zmiennej wartości ciśnienia tętniczego krwi, która zależna jest od licznych czynników zewnętrznych, istotne jest ścisłe przestrzeganie standardów pomiaru.

W przeprowadzonym badaniu wykazano, że w pomiarze CTK w warunkach domowych chorzy uzyskiwali przeważnie wyniki prawidłowe - średnia pomiaru, jak wspomniano - wynosiła 130,31/76,81 mm Hg. Natomiast podczas pomiaru gabinetowego badane osoby uzyskały znamiennie wyższe wartości ciśnienia tętniczego krwi. Według wytycznych Polskiego Towarzystwa Nadciśnienia Tętniczego dotyczących zasad postępowania w NT (2015) pomiary CTK w warunkach domowych zmniejszają ryzyko błędu związanego z wystąpieniem efektu białego fartucha czy też izolowanego nadciśnienia gabinetowego (ang. isolated office hypertension) oraz nadciśnienia zamaskowanego (ang. isolated abmbulatory hypertension). Wysiłek fizyczny i stres związany z wizytą lekarską, starszy wiek, płeć żeńska i niepalenie tytoniu mogą przyczyniać się do wzrostu ciśnienia tętniczego krwi w gabinecie. W wytycznych autorzy stwierdzają, że problem dotyczy ok. 55\% chorych. Zdarza się rzadziej, gdy pomiar dokonywany jest przez pielęgniarkę, a nie lekarza. Wciąż trwa dyskusja, czy tę grupę chorych traktować jak osoby z prawdziwą normotonią. Wytyczne stwierdzają, że u wymienionych chorych CTK należy kontrolować co sześć miesięcy i poszukiwać u nich ewentualnych powikłań narządowych zwłaszcza przerostu lewej komory i współistniejącej cukrzycy [4].

Przeprowadzona w niniejszej pracy analiza wariancji ANOVA z powtarzanym pomiarem potwierdza, że procedura wykonania pomiaru CTK ma wpływ na wartość wyniku. W traktowanej całościowo grupie 130 chorych z NT wykazano, że badani uzyskali najwyższe wartości ciśnienia w pozycji siedzącej zaraz po wejściu do gabinetu (pomiar $\mathrm{nr}$ 1), natomiast najniższe - w pomiarze $\mathrm{nr} 3 \mathrm{w}$ pozycji leżącej po 15 minutach od pomiaru $\mathrm{nr} 1$.

$\mathrm{W}$ badaniu nie wykazano istotnego wpływu płci, wieku, palenia papierosów ani BMI na zmienność CTK w zależności od procedury wykonania pomiaru. Tak więc niezależnie od wieku, płci, statusu osoby niepalącej/palacza tytoniu i klasyfikacji masy ciała, najwyższe wartości CTK skurczowego i rozkurczowego stwierdzono $\mathrm{w}$ pomiarze pierwszym w pozycji siedzącej, natomiast najniższe w pomiarze trzecim w pozycji leżącej. Również niezależnie od prowadzonej $\mathrm{u}$ danego chorego typu farmakoterapii hipotensyjnej (monoterapia, terapia dwulekowa, terapia wielolekowa) zmienność wyniku CTK była typowa, czyli wartość ciśnienia spadała od pomiaru nr 1 do pomiaru nr 3; zależność była znamienna statystycznie. 
Okazuje się jednak, że ta charakterystyczna zależność wyników CTK od procedury pomiaru przestaje mieć znaczenie w niektórych częstych chorobach towarzyszących nadciśnieniu. W niniejszej pracy wykazano po pierwsze, iż w przypadku osób chorych z cukrzycą nie wystąpiły różnice w zakresie wartości ciśnienia tętniczego skurczowego i rozkurczowego w zależności od procedury wykonania pomiaru. Pacjenci z cukrzycą mieli słabiej kontrolowane CTK i zażywali więcej leków hipotensyjnych. Było to zgodne z wynikami Shelley i wsp., w myśl których współistnienie cukrzycy, niezależnie od jej typu, pogarsza kontrolę NT i wymaga zastosowania większej liczby leków [19]. Potwierdzono tym samym pośrednio tezę Niedziałka i wsp., że współistnienie NT i cukrzycy wiąże się z około dwukrotnie wyższym ryzykiem niewyrównanego NT w porównaniu do osób niechorujących na cukrzycę i z koniecznością wdrożenia wielolekowej terapii hipotensyjnej dla osiągnięcia docelowych wartości CTK [17]. Z drugiej strony badania przeprowadzone przez Mete i wsp. u chorych z cukrzycą wykazały istotny wpływ niewłaściwej kontroli CTK na czas powstawania blaszek miażdżycowych w tętnicach szyjnych, ale nie na stopień kontroli glikemii [18].

W niniejszej pracy potwierdzono istotny wpływ insulinoterapii na wartość wyniku CTK, co przejawiło się nieoczekiwanie brakiem różnic wyniku ciśnienia tętniczego skurczowego i rozkurczowego w zależności od procedury wykonania pomiaru. Ponieważ jednak insulinę stosowano w oczywisty sposób tylko u podgrupy chorych z cukrzycą, więc obecności - lub nie - insulinoterapii u danego chorego prawdopodobnie nie można potraktować jak zmiennej niezależnej.

Także analiza grup chorych z astmą oskrzelową i POChP wykazała brak różnic w zakresie wartości CTK skurczowego i rozkurczowego w zależności od procedury wykonania pomiaru (pozycji ciała i czasu wykonania badania) (ryc. 12-15). Brak znamiennego wpływu pozycji ciała i czasu pomiaru na wynik CTK $\mathrm{w}$ astmie oskrzelowej i POChP jest kolejnym cennym i oryginalnym wynikiem niniejszej pracy. Według najlepszej naszej wiedzy w piśmiennictwie przedmiotu brak wyjaśnienia lub choćby odnotowania tej zależności. Jako możliwą przyczynę wskazujemy skłonność do hipoksji i wtórnej nadmiernej aktywacji układu sympatycznego. Chorzy ci zwykle leczeni są ponadto sympatykomimetykami. W sumie przypuszczalnie wysoka wyjściowo aktywacja adrenergiczna nakłada się na stres związany z pomiarem CTK gabinetowymi i zaciera różnice między kolejnymi trzema pomiarami. Problem wydaje się istotny, gdyż np. według badania epidemiologicznego grupy z pierwotnym NT, publikowanym w Medical Outcomes Study, astma i POChP należą do najistotniejszych współistniejących z nadciśnieniem chorób układu oddechowego [20]. W takich przypadkach wskazane jest użycie selektywnych beta-1 adrenolityków bez wewnętrznej aktywności sympatykomimetycznej w celu zmniejszenia ryzyka zaostrzenia chorób dróg oddechowych w przebiegu leczenia NT [21]. Z tymi danymi korespondują pośrednio wyniki niniejszego badania, wg których współwystępowanie astmy lub POChP skutkuje znamiennym pogorszeniem kontroli NT. Wydaje się, że lekarze 
prowadzący niepotrzebnie ograniczają stosowanie terapii beta-adrenolitycznej $\mathrm{w}$ tej grupie chorych.

Typowej zmienności wyniku pomiaru CTK nie stwierdzono również w nielicznej grupie chorych z przebytym zawałem serca lub udarem mózgu. Interpretacja tej obserwacji jest utrudniona ze względu na małą liczebność tych podgrup, złożone zaburzenia regulacyjne u chorych po incydencie sercowo-naczyniowym oraz brak w dostępnym nam piśmiennictwie istotnych publikacji dotyczących tego zagadnienia.

\section{Wnioski}

1. Wykazano istotną zmienność wyniku pomiaru CTK w zależności od pozycji chorego oraz czasu wykonania pomiaru bez względu na płeć, wiek i BMI badanych oraz zastosowane leczenie hipotensyjne.

2. Najwyższe wartości CTK stwierdzono w czasie pierwszego pomiaru wykonanego w pozycji siedzącej zaraz po wejściu do gabinetu; niższe w czasie drugiego pomiaru w pozycji siedzącej po upływie 10 minut; najniższe po upływie 15 minut w pozycji leżącej. Różnice między poszczególnymi pomiarami były znamienne statystycznie.

3. Nie stwierdzono występowania zmienności wyników pomiaru CTK u chorych z cukrzycą I ani II typu, astmą oskrzelową lub POChP, co może wynikać z powikłań naczyniowych i nerwowych choroby (cukrzyca) lub stosowanego leczenia (POChP, astma oskrzelowa).

4. Pomiar CTK w warunkach lekarskiej porady gabinetowej nie powinien być wykonywany zaraz po wejściu chorego do gabinetu, a wynik należy interpretować ostrożnie.

\section{Bibliografia}

1. Suligowska K i wsp. Niedostateczna wiedza Polaków na temat kryteriów nadciśnienia tętniczego i jego powikłań - wyniki badania NATPOL 2011. Nadciśnienie Tętnicze. 2014; 18 (1): 9-18.

2. Wojciechowska M, Izbeska E. Profilaktyka nadciśnienia tętniczego. Medycyna Ogólna i Nauki o Zdrowiu. 2014; 20 (4): 370-373.

3. Tykarski A, Narkiewicz K, Gaciong Z i wsp. Zasady postępowania w nadciśnieniu tętniczym. Wytyczne Polskiego Towarzystwa Nadciśnienia Tętniczego. Nadciśnienie Tętnicze w Praktyce. 2015; 1: 1-33.

4. Mancia G i wsp. Wytyczne ESH/ESC dotyczace postępowania w nadciśnieniu tętniczym w 2013 roku. Grupa Robocza Europejskiego Towarzystwa Nadciśnienia Tętniczego (ESH) i Europejskiego Towarzystwa Kardiologicznego (ESC) do spraw postępowania w nadciśnieniu tętniczym. Kardiologia Polska. 2013; 71, supl. III: $27-118$. 
5. Rajzer M. Podatność tętnic w nadciśnieniu tętniczym. Od patofizjologii do znaczenia klinicznego. Arterial Hypertension. 2002; 6 (2): 61-73.

6. Zamojski M. Role of autonomic nervous system in the pathomechanism of hypertension. Arterial Hypertens. 2016; 20: 21-25.

7. Weakley S. Arterial baroreceptors in the management of systemic hypertension. Medical Science Monitor. 2010; 16: 1-8.

8. O'Brien E, Waeber B, Parati G i wsp. Blood pressure measuring devices: recommendations of the European Society of Hypertension. BMJ. 2001; 322: 531-536.

9. Wojciechowska M. Profilaktyka nadciśnienia tętniczego. Medycyna Ogólna i Nauki o Zdrowiu. 2014; 20: 370-373.

10. Prejbisz A, Januszewicz A. Postępowanie w nadciśnieniu tętniczym w świetle wytycznych amerykańskich 2017. Med. Prakt. 2018; 2: 30-38.

11. Whelton PK, Carey RM. The 2017 clinical practice guideline for high blood pressure. JAMA. 2017; 318: 2073-2074.

12. Viera A. Ambulatory blood pressure phenotypes and risk for hypertension. Current Hypertension Reports. 2014; 16 (10): 1-6.

13. Grabańska K. Miejsce leczenia niefarmakologicznego w prewencji i terapii nadciśnienia tętniczego. Forum Zaburzeń Metabolicznych. 2010; 1 (2): 115-122.

14. Stępień-Wałek A. Ciśnienie tętnicze w pomiarach gabinetowych a całodobowe monitorowanie ciśnienia tętniczego u pacjentów leczonych hipotensyjnie. Arterial Hypertension. 2013; 1: 184-190.

15. Strepikowska A. Udar mózgu - czynniki ryzyka i profilaktyka. Postępy Farmakoterapii. 2009; 65 (1): 46-50.

16. Tykarski A. Inhibitory konwertazy angiotensyny - zmniejszenie śmiertelności u pacjentów z nadciśnieniem tętniczym. Nadciśnienie Tętnicze. 2012; 16 (4): 210215.

17. Niedziałek J. Porównanie leczenie nadciśnienia tętniczego u pacjentów ze wspótistniejaca cukrzyca typu 2 i bez cukrzycy. Medycyna Ogólna i Nauki o Zdrowiu. 2012; 18 (1): 45-48.

18. Mete M. Relationship of glycemia control to lipid and blood pressure lowring and atherosclerosis. Journal of Diabetes and its Complications. 2011; 25 (6): 362-367.

19. Shelley D. Predictors of blood pressure control among hypertensives in community health centers. American Journal of Hypertension. 2011; 24 (12): 1318-1326.

20. Grabicki M. Leczenie nadciśnienia tętniczego u pacjentów z przewlektymi chorobami układu oddechowego. Forum Medycyny Rodzinnej. 2007; 1 (2): 95-108.

21. Rutten FH, Zuithoff NP, Halk F i wsp. Beta-Blockers may reduce mortality and risk of exacerbations in patients with chronic obstructive pulmonary disease. Arch Intern Med. 2010; 170: 880-887. 


\title{
Variability of the blood pressure results depending on its measurement procedure in patients with controlled idiopathic hypertension
}

\begin{abstract}
Introduction: Hypertension is a common condition requiring systematic effective treatment to prevent severe complications such as heart attack, stroke, heart failure. The pharmacotherapy and drug doses depend on the results of blood pressure (BP) measurements performed by patients themselves, as well as by physicians and other health professionals. In order to reach the correct therapeutic decisions, the cabinet BP measurement needs to be standardized.

The aim of the study was to determine the variability of three subsequent BP measurements in the same patient depending on sex, age, body mass index (BMI), smoking, antihypertensive treatment and concomitant selected chronic diseases, i.e. diabetes mellitus (DM), chronic obstructive pulmonary disease (COPD), bronchial asthma (BA).

Material and methods: In 130 patients with primary hypertension in the office, three BP measurements were performed: 1 . in a sitting position immediately after entering the office; 2. after 10 minutes in a sitting position; 3 . after 15 minutes in a lying position. BMI, comorbidities, current medication and smoking status were collected on the basis of medical records.

Results: A statistically significant variability in BP measurement results was found. It depended on the position and time of the measurement; this finding was regardless of sex, age, BMI and type of antihypertensive treatment. There were no variations in measurement results in patients with DM, COPD or BA. The highest BP values were found at the first measurement, the lower at 2nd and 3rd one.

Conclusions: Body position and time from the visit onset to the BP measurement affect it's result, except the groups of patients (DM, COPD, BA) in which the pharmacotherapy side effects can eliminate the difference. The study results confirm the need for careful assessment of the results of cabinet BP measurements.
\end{abstract}

Key words: antihypertensive treatment, blood pressure measurement, primary hypertension 